Ethiopian Journal of Environmental Studies \& Management 8(6): 635 - 649, 2015.

ISSN:1998-0507

doi: http://dx.doi.org/10.4314/ejesm.v8i6.3

Submitted: January 11, 2015

Accepted: August 10, 2015

\title{
DETERMINANTS OF PARTICIPATION OF RURAL FARM HOUSEHOLDS IN NON-FARM ACTIVITIES IN KWARA STATE, NIGERIA: A PARADIGM OF POVERTY ALLEVIATION
}

\author{
${ }^{*}$ OLADIMEJI, Y.U., ${ }^{1}$ ABDULSALAM, Z. ${ }^{1}$ AND ABDULLAHI, A.N. ${ }^{2}$ \\ ${ }^{1}$ Department of Agricultural Economics and Rural Sociology, Ahmadu Bello University, \\ P.M.B. 1044, Zaria, Kaduna State, Nigeria \\ ${ }^{2}$ Department of Agricultural Economics, Usmanu Dan Fodiyo University, Sokoto, Nigeria
}

\begin{abstract}
This paper attempt to examine the factors that determine non-farm occupations among rural farming households and to what extent has livelihood strategies improved the wellbeing of their households. Primary data were generated through random sampling of 200 respondents from four (4) Local Government Areas (LGAs) in Kwara State, Nigeria through field surveys. Descriptive statistics, double hurdle models and Foster-Greer-Thorbecke (FGT) index were employed in the analysis. The result confirmed the assertion that economic factors are often the most important determinants of searching for non-farm job. The proceeds from non-farm activities were used mainly either for consumption (34.5\%) to minimize the income fluctuation or, to supplement the working capital (26.5\%) for their primary occupation through purchase of farm inputs. The results also indicated that the factors that influence the rural farming household decision to participate in non-farm activities showed slight variation from those influencing level of decision (livelihood strategies) taken to engage in non-farm activities and where it does, not by the same magnitude and direction. For instance, distance travelled and adjusted household size was found to significantly influence the farmer's decision. In contrary, education, poverty status and per capita income did influence the level of participation significantly. Of the sampled 200 respondents, 49.5\% live on less than US\$1 a day which portends extreme poverty and about $87 \%$ on less than US $\$ 1.5$ a day. Concerted effort by stakeholders must encourage continuous farming throughout the year through irrigation to avoid part-time farming which may become the dominant farm model.
\end{abstract}

Key Words: Extreme poverty, rural households, service sector, Nigeria

\section{Introduction}

Nigeria is a relative large country which occupies about 923,768 square kilometres and agriculture is the main stay of its economy, providing the food need of the teaming population of about 163 million and employing close to $70 \%$ of the people who are mostly rural dwellers (Oladimeji et al., 2013). According to Jama'are (2002), despite the discovery of oil in the early 1970's, the agricultural sector is still the most important sector of the national economy in terms of rural employment, provision of food and export earnings. It provides employment to about two-thirds of Nigeria's adult labor force (CBN, 2006). It still provides $88 \%$ of non-oil earning out of which crop production takes $51 \%$

*Corresponding author: Oladimeji Y.U.

Email: yusuf.dimeji@yahoo.com 
(Economic Associate, 2010). At the same time, the share of the agricultural sector in GDP has declined from 56\% in 1960-1964 to about $35 \%$ from 2008 till date (NBS,2012; FAO, 2013). Ironically, the share of labour force in agricultural sector put at about $2 / 3$ of active labour force has not widened significantly.

The performance of the Nigeria economy has improved in recent years. The gross domestic product (GDP) grew by about $7 \%$ in 2012 and 2013 respectively and is currently projected to grow at $6 \%$ or more in 2014 (NBS, 2013).Despite his large natural resource endowment, agricultural potential and human resources, the historical records of its economy show that development remain a critical challenges as reflected in its inadequate infrastructure, its low domestic investment rates, the slow pace of upgrading local technology and alleviating poverty, weaknesses in governance and insecurity. Even though agriculture is growing in terms of total value and jobs created, the rise in the contribution of services sector such as the telecommunications (8.5\%) and wholesale and retail trade $(23.7 \%)$ in 2013 has led to the reduction of agriculture contribution as a proportion of total GDP to about $35 \%$ (NBS, 2013). The implication of this is that Nigeria is moving towards a more service-oriented economy.

The services sector comprises domestic trade, tourism/hotel and restaurant, transportation, post and telecommunications, social services, utilities, finance and insurance and real estate. The service sector remains a major growth driver in the Nigerian economy, accounting for $65.89 \%$ and $54.89 \%$ of the total GDP growth in 2008 and 2009 respectively (NBS, 2010). The service sector has contributed about 53\% to GDP in the first quarter in 2014 accounting for over half of GDP growth (NBS, 2014). As a result, per capita income of Nigeria has more than tripled over the period of year 2000 , though to a medium base, it was still $\$ 2,069$ as of 2011compared to World per capita income of $\$ 10,082$, which still made the country one of the poorest in the world (Oladimeji et al., 2014).

However, the rural farming households play a significance role in service sector mostly during the off-farm season to get work for sustaining their livelihood such as cushion food shortage experienced by the households or settle domestic obligation and buy back some inputs needed for farming operations. Hence, they go in search of all kind of non-farming jobs mostly casual labour in industries, craft, artisan work and, public and private institutions located near their villages. A handful of these households migrate temporarily to urban centres to search for jobs. They converge with urban job seekers and assemble at designated centres in major street corners of Ilorin and other cities in Nigeria in form of labour markets as also observed by Ali, (2014) in urban labourers found in Ethiopia. Such type of markets is common in developing nations where unemployed of different age groups, educated and illiterate assemble to get work for earning their livelihood.

\section{Statement of Problem}

It is clear from above that rural farming households also engage in wide range of income-generating activities for livelihood. Broadly, this can be categorized into "farm activities" and "non-farm activities" (Eboh, 2000). Non-farm income is increasingly important in the livelihood of Nigeria rural household. Evidence from literature revealed that there has been an increasing recognition recently that the rural economy is not confined to the agricultural sector, but embraces the broad spectrum of needs of all rural people including social service provision, economic activities, 
infrastructure and natural resources (Csaki and Lerman, 2000; Davis and Bezemer, 2004; Idowu et al., 2013). In addition, the economic diversity in the rural area has the potential to foster local economic growth and alleviate the rural-urban income gap and rural poverty (Davis and Bezemer, 2004).

Literature further revealed that involvement of rural farm households in non-farm activities exhibits higher potentials of reducing rural unemployment rate as well as increasing household income (Nicodemo, 2007; De Janvry et al., 2005). Thus, many research work recommended that the non-farm employment should be developed more particularly among farm households in order to increase share in household income (Lanjouw and Murgai, 2009; Davis et al., 2009, Idowu et al., 2011).Consequently, the rural economy is not based only on Agriculture but rather on a diverse array of activities and enterprise (Reardon et al., 2001). Considering the growing importance of the non-farm activities among the rural households in developing countries, the study therefore, intends to examine factors that determine non-farm occupations among rural farming households and to what extent has nonfarm activities (livelihood strategies) improved the well-being of their households in Kwara State, Nigeria.

\section{Hypothesis}

(i) There is no significance difference between farm income with and without additional earning/secondary occupation.

(ii) Secondary occupations do not improved the economic well-being of the households in the study area

\section{Methodology Study Area}

Kwara State is situated in North Central Nigeria with Ilorin as capital. It is located between latitude $7^{\circ} 45^{\prime}$ and $9^{\circ} 30^{\prime} \mathrm{N}$ and longitude $2^{\circ} 30^{\prime} \mathrm{E}$ and $6^{\circ} 25^{\prime} \mathrm{E}$ with a land mass covering about 32,500 sq. $\mathrm{km}$ and a total land size of $3,682,500$ ha. With an estimated population of 2.4 million people (NPC, 2006), the State's population and farm families were projected in 2015 to be about 3.09 million and 305,990 respectively representing $3.2 \%$ annual growth rate and an average density of 95 persons per sq. $\mathrm{km}$ with majority living in rural areas.

The study was carried out in Kwara North and Asa LGAs, being predominantly farming area of Kwara State, Nigeria. The major markets, industries and tertiary institutions in the State are located in this area. Small and household level industries by formal and informal sectors such as Songhai farm, Quarry firms, Bacita and Lafiagi sugar companies, Jebba paper mill and Kam wire industry are situated in the study area. Others are Global soap and detergent, Unifoam, 7up Bottling Company, Tuyil pharmaceuticals, Nigeria Bottling Company, Kwara State Polytechnic and University as well as College of education (Technical) Lafiagi. Construction works both private and public and transactions of agricultural commodities through local markets, hoteliers and basic infrastructure works are also sources of non-farm employment and livelihood occupations among the inhabitations. 


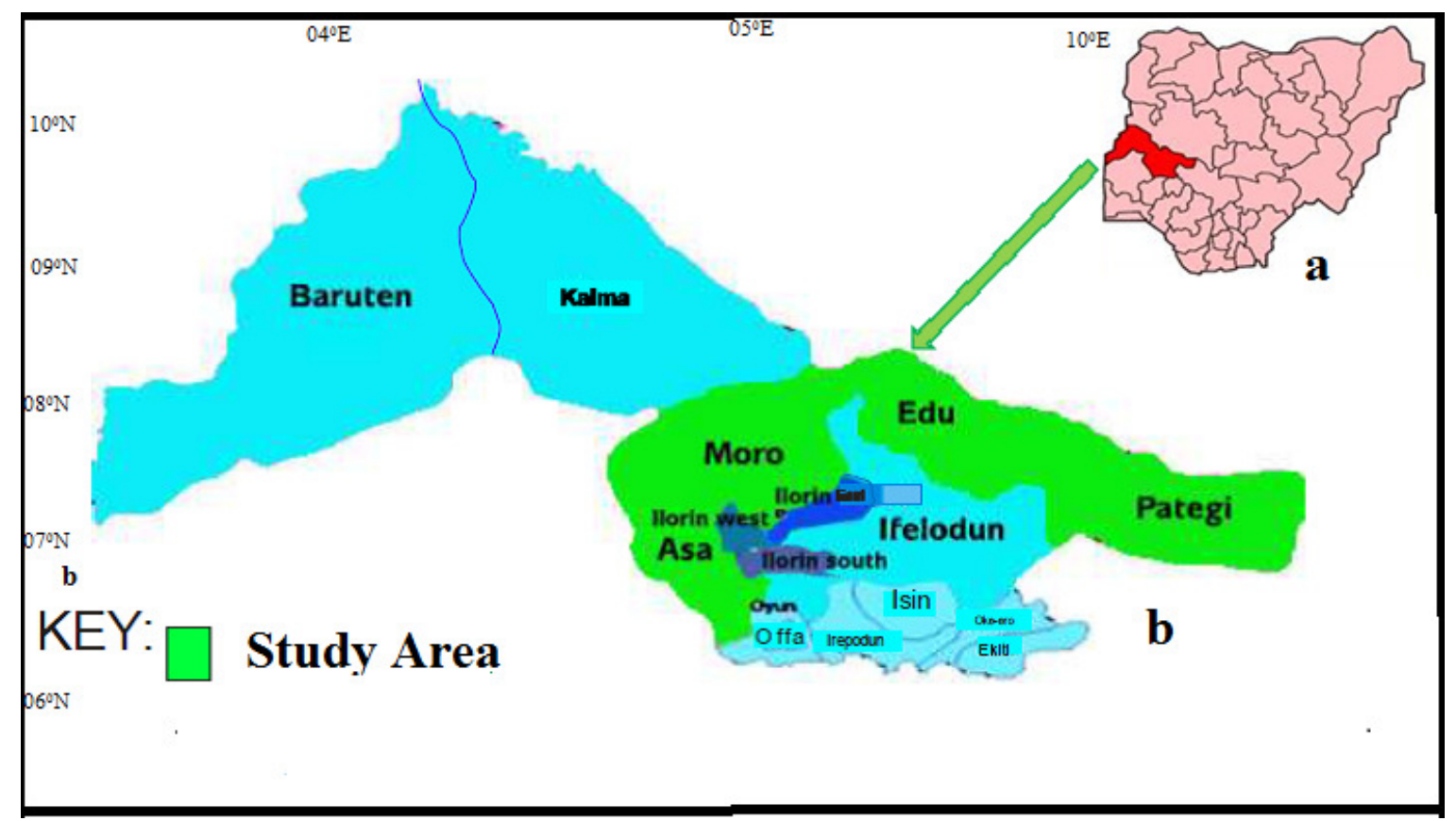

Figure 1: Map of Nigeria (a) and Location map of the Study Local Government Areas(b) \{modified from NPC, (2006)\}.

\section{Data Collection}

The study is based on primary sources of the data gathered by field surveys in 2013/2014 off-farming season through questionnaire and interview. Specifically, it focused on socio-economic characteristics and data on secondary occupations.

\section{Sampling Procedure and Sampling Technique}

The analysis in this paper was based on a multi stage random household survey conducted in four (4) LGAs viz. Asa, Edu, Moro and Patigi in 2013/2014 off-farming season. The LGAs were purposively selected being an area with farming households that have myriads opportunity to other ancillary jobs in their surroundings. Two villages each were randomly selected from each of the 4 LGAs. Then, 25 farming households were randomly selected from each of the village to make a total of 200 respondents. The selected villages were Ogbondoroko, Laduba (Asa);Onipako, Beriberi (Moro);Songahi, Bacita (Edu) and Ellah, Sunkuso (Patigi).

\section{Analytical Techniques}

The determinant of non-farm resource allocation to various categories of non-farm activities by the individual farm household is a two-stage decision process: viz. decision to participate, and level of participation. There are two main reasons for separating these decisions. First, due to social-demographic or psychological drives, some farming households may not participate in any non-farm activity as a result of the prevailing relative wage rates, distance to urban centres, pressure from farm work, local-level involvement in social and religious organizations and many other possible factors. Secondly, a household head may see the needs to get extra income (livelihood strategies) to upset food and other basic needs for the households but for certain levels of relevant variables, decide not to respond. The former represents abstention, the latter a corner solution. Damisa et al. (2011) 
observed that the application of either multiple regression or one step tobit regression analysis for a cross sectional data of this nature can be misleading, for most of cross-sectional income/consumption data, zero income/consumption is one problem for any modelling effort to address.

In addition, two disadvantages of using one step tobit model are that all zero observations on level of decision to participate in non-farm activities (livelihood strategies) undertaken to get extra earning to cater for household basic needs such as combating the food shortage in the household are interpreted as corner solutions, that is, the household is assumed to perceive the problem of need for extra earning (participation) but chooses not to respond at the current level of exogenous variables. A further restriction of the Tobit is that both decision to participate and level of participation undertaken to cater for the household basic need are determined by the same variables, that is, a variable that influences the decision to participate also influences the level of participation or extra earning (livelihood strategies) undertaken.

Several studies have used binary choice models in determining perception and the response decisions where the perception and the response resulting from the perception were viewed as a single step process. However, the study employed double-hurdle model in determining decision to participate and livelihood strategies where the decision and the level of participation resulting from the decision were viewed as a two-step processes. In other words, decisions to participate and its level are viewed as separate hurdle that needed to be crossed.

The double-hurdle model was originally proposed by Cragg (1971) adopted in agricultural technology adoption studies by (Damisa et al., 2007; Shiferaw et al.,
2008); consumer demand and market participation studies by (Weersink, 1992; Matshe and Young, 2004; Serra et al., 2005; Damisa and Hassan, 2009; Idowu et al., 2013).It assumes that two separate hurdles must be crossed before a positive level of consumption/income can be observed. In the context of the household decision and level of response analysis, the first hurdle involves the decision of whether or not the household see the needs to get extra earning (income) to upset food and other basic needs for the household (participation decision). It is reasonable to assume that the choice to perceive needs in household by the household head is not only an economic decision, but also influenced by social and demographic factors. The second hurdle concerns the type /number of livelihood strategies to choose (response decision). A different latent variable was used to model each decision process (Damisa et al., 2011).

Following the standard practice in related studies (Matshe and Young, 2004; Serra et al., 2005; Idowu et al., 2013), the decision to participate in non-farm activities was addressed by fitting a logit model while its level (livelihood strategy)was addressed by fitting Tobit regression model for only those households that claimed to participate in non-farm activities. Therefore, the underlying response variable $\mathrm{y}^{*}$ in the case of binary choice was econometrically specified by the multivariate logit regression relation in equation 1

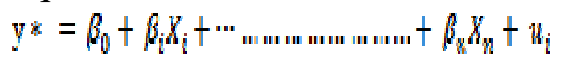

Where: $\mathrm{y}^{*=}$ the probability that a household will participates in non-farm work and ranges from 0 to $1 ; X_{i}=$ the ith explanatory variables which are parameters to be estimated (Oladimejiet al., 2015).

Following Goodwin and Mishra (2004); El Osta et al. (2004); Damisa et al. (2011) and 
Idowu et al. (2013), the Tobit model was used, thus:

$$
\begin{aligned}
& Y_{i}^{*}=\sum \mathrm{X}_{\mathrm{i}} \beta+\mu_{\mathrm{i}} \ldots \ldots \ldots \ldots \ldots \ldots(2) \\
& Y_{i}=P_{i}=\left(\mathrm{X}_{\mathrm{i}} \beta, \mu_{\mathrm{i}}\right) \text {, if } \mathrm{P}_{\mathrm{i}}>\mathrm{P}_{\mathrm{i}}^{*} \\
& 0=\left(\mathrm{X}_{\mathrm{i}} \beta, \mu_{\mathrm{i}}\right), \text { if } \mathrm{P}_{\mathrm{i}} \leq \mathrm{P}_{\mathrm{i}}^{*} \\
& \mathrm{i}=1,2 \ldots, \mathrm{n}
\end{aligned}
$$

Where: $Y_{i}=$ the dependent variable. $Y_{i}^{*}$ is the vector of variables indicating the extent of livelihood strategies of household or otherwise in non-farm activities. $\beta$ is a vector of unknown co-efficient and $\mu \mathrm{i}$ is an independently distributed error term. $\mathrm{Xi}$ is a vector of explanatory variables (Oladimeji, 2015).The model was estimated using maximum likelihood estimation procedures. Table 1 shows the description and measurement of variables employed in the double-hurdle model estimation.

A Foster-Greer-Thorbecke (FGT) index was used to determine the influence of income with or without subsidiary earning on welfare of rural farmers given as:

$p_{a i}=\frac{1}{n} \sum_{i=1}^{q}\left(\frac{z-y_{i}}{g}\right)^{a}$

Where: $P_{a i}$ is the poverty index for the $\mathrm{i}^{\text {th }}$ sub-groups, $\mathrm{n}$ is the total number of households, $\mathrm{Y}_{\mathrm{i}}$ is the per adult equivalent income/consumption expenditure of $\mathrm{i}$-th households, $\mathrm{z}$ is the poverty line, $\mathrm{q}$ is the number of the sampled household population below the poverty line and $\alpha$ is the aversion to poverty it ranges from 0 to 2 (Foster et al., 1984).

Table 1: Measurement of variables and a priori expectations

\begin{tabular}{ll}
\hline Variables & Description and a priori expectations \\
\hline Decision & $1=$ If a household participate in any of the non-farm activities during the season \\
Level of participation & It otherwise \\
& It is the rank level of participation (livelihood strategies) by the household head \\
& or any household member in improving the economic well-being of the \\
& households above the poverty line. The value $=1$ if any member of the household \\
& or household head were employed in non-farm skilled labour; $=2$, if employed in \\
& non-farm unskilled labour; =3, if employed in paid social or community service; \\
& $=4$, if received remittance from other households; $=5$, if the rank take on the \\
& value of 1 and any of $2-4 ;=6$, if the rank take on the value of any or all \\
& combinations of $1-4$.
\end{tabular}

Age Age of the household head in years; positive

Education $\quad$ Years spent in a formal education by the household head; negative

Adjusted household size Number of dependents per household head; positive

Distance

Distance to the nearest city $(\mathrm{Km})$; positive

Credit accessed Amount of credit accessed during the production season (N); negative

Poverty status Poverty status of household (poor $=1,0$ otherwise); negative

Per capital income Adjusted income in the non-farm relative to agriculture (N); negative

Social organisation $\quad$ Years of membership of farming cooperative society; negative

Note: denote Nigeria currency (Naira); 1US \$= Average 164.5 during the field survey

\section{Results and Discussion}

\section{Socio-economic Characteristics}

Summary statistics of the data reported in Table 2 revealed that rural household heads that engaged in non-farm occupations in the study area are males dominated (95\%); average age of 48 years and married $(71 \%)$ with mean household size of 8and adjusted size of 7.Therefore, it could be concluded that the preponderance of active and virile heads of households in the study area has a multiplier effects on increased availability of able bodied labour 
for both primary production (farming) and secondary occupation.

Education is considered a key to expand the horizons of the minds and to develop thinking to live good social and economic life (UN, 2005;UNICEF, 2010). But, the estimated mean years of schooling of sampled household heads are 1.09 years, a reflection of deprived training conditions, skewed towards the informal education and below UNDP, (2011) mean education index of 5 years for Nigeria. The study also revealed that $75 \%$ of the household heads had no access to credit facilities from either formal or informal sources. It suffices to note that the bulk of proceeds from both secondary and off farm income $(61 \%)$ are designated for consumption and purchase of inputs in preparation for farming production. The findings on socioeconomic data is comparable with Idowu et al. (2013); Oladimeji et al. (2015).

Table 2: Definition and dominance indicators of the socio-economic variables

\begin{tabular}{lllll}
\hline Variables description & Dominance indicators & Mean & Min & Max \\
\hline Gender & $95 \%$ were male & - & -- & -- \\
Age (years) & $58 \%$ below 50 years & 48 & 23 & 68 \\
Level of education (years) & $53 \%$ had no primary education & 1.09 & 0 & 12 \\
Adjusted household size & $74 \%$ had adjusted size of 7-9 & 8 & 3 & 14 \\
Distance travelled (km) & $65 \%$ travelled at least 15km & 18.9 & 5 & 43 \\
Credit accessed (N) & $75 \%$ had no credit access & 22760 & 0 & 98000 \\
Per capita income (N) & $52 \%$ earned <\#70,000/annum & 65700 & 42500 & 98750 \\
Social organisation (yrs) & $65 \%$ were passive member & 24 & 6 & 38 \\
Poverty line (income) & $58 \%$ were below 2/3 per AE & & \\
Consumption \& inputs & $61 \%$ used the proceeds from non-farm activities for both items \\
\hline
\end{tabular}

Results in Figure 2 revealed that family members of the sampled rural households were mainly engaged as domestic servants (27\%), trading $(24.3 \%)$, artisan labourers (21.3\%), catering/restaurant workers (13.3\%), commercial motor cycle and bus conductors $(10 \%)$ and others $(4 \%)$ which include selling farm products, hunting, weaving (cloth and basket) and woodcarving. The implication of these findings were also similar to what Oladimeji, (1999); Olaoye et al. (2012) pointed out that the rural farming households have diversified farming oriented economy and has developed capacity to cope with increasing vulnerability associated with fishing or farming, such as diversification and migration. Diversification as a strategy involves the attempt by individuals and households to find new ways to raise income and reduce risk. Ellis, (1998) and Nasai (2008) stated that it is evident that rural households in Nigeria engaged in multiple activities such as trading (marketing or adding value to commodities), small scale business enterprises (carpentry, radio and bicycle repairs), processing of agricultural goods, arts and crafts (weaving, mats and basket making) in order to supplement earnings from agriculture.

Meanwhile, result in Table 3 shows the plan usage of income earned from ancillary and non-farm activities. It was found that majority of the rural households who seek for secondary and non-farm employment in the rural areas or migrate temporarily to urban centres either in the formal or informal sector used the proceeds for either consumption $(34.5 \%)$ to minimize the income fluctuation during off-farm season 
and or drought or, to supplement the working capital $(26.5 \%)$ for their primary occupation through purchase of farm inputs. Other reasons mentioned were to foster education of their wards and family health care $(8.5 \%)$ and repairs and construction of residential building (8\%) which shows that rural households are aware of value of education and health care and, decent and comfortable abode which are grossly lacking in the study area. This confirmed the studies by Damisa et al. (2011) and Ali, (2013; 2014) as well as assertion by Akangbe et al. (2006) that economic factors are often the most important determinants of searching for off-farm job.

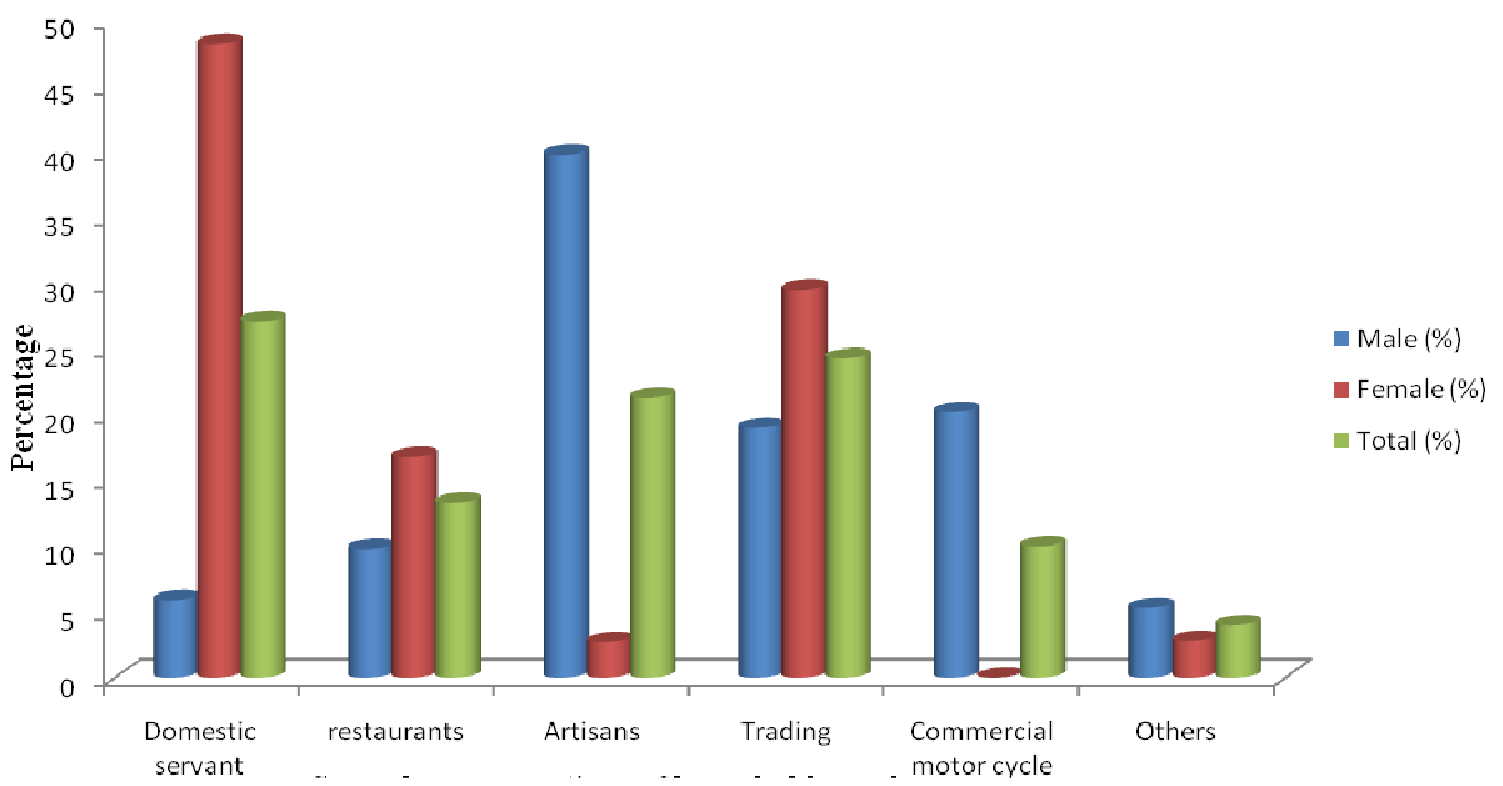

Figure 2: Secondary Occupation of Household Members

Table 3: Planned usage of income earned from ancillary and non-farm activities

\begin{tabular}{lllll}
\hline \multirow{2}{*}{ Planned usage } & \multicolumn{5}{l}{ Main occupation of households } \\
& Total & Arable & Fishing & Agricultural \\
& & cropping & & labour \\
\hline Purchase of farming inputs & $53(26.5)$ & 14 & 39 & 0 \\
Purchase of livestock & $20(10.0)$ & 11 & 7 & 2 \\
Consumption & $69(34.5)$ & 20 & 37 & 12 \\
Savings & $15(7.5)$ & 3 & 5 & 7 \\
Repair \& construction of house & $16(8.0)$ & 6 & 4 & 6 \\
Education \& health & $17(8.5)$ & 5 & 3 & 9 \\
Others & $10(5.0)$ & 2 & 5 & 3 \\
Total & $200(100)$ & $61(30.5)$ & $100(50.0)$ & $39(19.5)$ \\
Mean & 28.57 & 8.71 & 14.29 & 5.57 \\
Standard deviation & 22.82 & 6.58 & 16.26 & 4.20 \\
\hline
\end{tabular}

Note: figure in parenthesis are \%

Table 4 depicts per capita household's income per annum without supplement or secondary occupation while Table 5 present per capita household's income per annum with supplement earning either in form of secondary occupation or non-farm earning and regular remittance from friends and relatives. Of the sampled 200 respondents, 
almost half (49.5\%) live on less than US\$1 a day which portend extreme poverty (UNDP, 2005) and about $87 \%$ on less than US $\$ 1.5$ a day. However, with access to secondary occupation, a handful of rural household heads $(6.8 \%)$ achieved a threshold of US $\$ 2$ a day and according to UNDP, (2005), almost half of the world population, live on less than US \$2 a day. The result also revealed that with opportunity to supplement their income with both secondary or non-farm earning and remittance from family and friends, only $32 \%$ live on less than US\$1 a day and about $62.7 \%$ on less than US $\$ 1.5$ a day.
Further, the study shows that secondary occupation could have increase the income of rural households more considerably but most rural household heads and their household members did not have access to continuous work for all days of the offfarm season couple with unbar-gain and poor wages. The result was consistency with findings of Ali, (2014) who observed that majority (about 73\%) of daily labourers in Ethiopia together with family members survive on less than US \$2 per day.

TABLE 4:Distribution of /capita household head's income/annum without ancillary earning

\begin{tabular}{llll}
\hline Household Income (N) & Household Income (USD:\$) & Total Sample & \% Contribution \\
\hline $20000--40000$ & $121.58--243.16$ & 32 & 16.0 \\
$40001--60000$ & $243.17--365.00$ & 67 & 33.5 \\
$60001--80000$ & $365.01--486.32$ & 59 & 29.5 \\
$80001-100000$ & $486.33--607.90$ & 23 & 11.5 \\
$>100000$ & $>607.90$ & 19 & 9.5 \\
Total -- & - & 200 & 100 \\
Mean 46 752.50 & $2 / 3=31168.3$ (poverty line) & -- & -- \\
\hline
\end{tabular}

Note: the income was adjusted to per adult equivalent; $U S D=\$$

Table 5: Distribution of / capita household head's income/annum with ancillary earning

\begin{tabular}{llll}
\hline Household Income (N) & Household Income $(\$)$ & Total Sample & \% Contribution \\
\hline $20000--40000$ & $121.58--243.16$ & 23 & 11.5 \\
$40001--60000$ & $243.17--365.00$ & 41 & 20.5 \\
$60001--80000$ & $365.01--486.32$ & 59 & 29.5 \\
$80001-100000$ & $486.33--607.90$ & 49 & 24.5 \\
$>100000$ & $>607.90$ & 28 & 14.0 \\
Total -- & -- & 200 & 100 \\
Mean 67500.90 & $2 / 3=45000.6$ & -- & -- \\
\hline
\end{tabular}

Factors Influencing Farming Household Decision and Level of Participation

Table 6 shows the estimates of the double hurdle regression model. The results indicated that the factors that influence the rural farming household decision to participate in non-farm activities showed slight variation from those influencing level of decision (livelihood strategies) taken to engage in non-farm activities and where it does, not by the same magnitude and direction. For instance, distance travelled and adjusted household size were found to significantly influence the farmer's decision. In contrary, education, poverty status and per capita income did influence the level of participation significantly.

Adjusted household size and per capital income were the most important variables that significantly influenced the first and 
second hurdles $(\mathrm{P}<0.05)$. This was consistency with a priori expectations. For example, per capital income is an important factor in determining the poverty status of a household and an increase in extra income will decrease the propensity of a farmer falling below the poverty line. Households with sufficient farm income and negative poverty status may have negative likelihood effect on engagement in selfemployment, that is, being less poor significantly increased the probability of participating in non-farm self-employment (Idowu et al., 2013).

The adjusted household size variable was significantly positively related with the household's decision to participate $(\mathrm{p}<0.05)$; however, the variable had a significant negative relationship $(\mathrm{p}<0.01)$ with the extent of participation (livelihood strategy) in the household. The implication of the inverse relationship with level of participation was that the less the household size, the rapid they were able to make decision to participate less in nonfarm activities. Both credit accessed and cooperative membership were insignificant in the 2 hurdles. Cooperatives were supposed to train and render other forms of welfare assistance to their members
(Damisa et al., 2011) while credit is one of the policy instruments which could promote farm technology transfer and increase farm income. The insignificance of these variables could mean that the cooperatives were inactive while lack of credit or its inadequacy was most likely to affect farming operations negatively.

Measuring Poverty Incidences with and without non-farm income

The study used and consider the relative poverty measurement among others for a number of reasons. The advantage of this method over the dollar per day lies not only in its simplicity but in the fact that the poverty line is determined in relation to the general living standard of the whole target population and the ability to assess changes in the living standard of the people over time (Oladimeji et al., 2014). Also in relation to other members of a community there would always be relative poverty. Overall, about $42 \%$ of sampled household heads fell below poverty line of $\$ 31168.3$ per capita per year without extra earning from secondary occupation while only $25 \%$ could not meet a threshold of 45000.6 when the income from secondary occupations were included.

Table 6: Estimates of decision and extent of participation (Double Hurdle Model)

\begin{tabular}{lll}
\hline Variable & $\begin{array}{l}\text { First Hurdle equation } \\
\text { (Decision) }\end{array}$ & $\begin{array}{l}\text { Second hurdle equation } \\
\text { (Extent) }\end{array}$ \\
\hline Age & $0.021(1.08)$ & $0.152(0.69)$ \\
Level of education & $0.362(0.98)$ & $-0.097 * *(1.99)$ \\
Adjusted household size & $0.621 * *(2.29)$ & $-0.430 * * *(3.70)$ \\
Distance travelled & $0.009 * *(4.01)$ & $0.062(1.14)$ \\
Credit accessed & $-0.727(0.08)$ & $0.176(1.50)$ \\
Poverty status & $0.053(1.52)$ & $-0.092^{* *}(2.07)$ \\
Per capital income & $0.681 * *(2.30)$ & $0.521 * *(2.35)$ \\
Cooperative membership & $-0.510(1.06)$ & $0.275(1.24$ \\
Constant & $-0.032\left(1.78^{*}\right)$ & $0.022(3.42 * * *)$ \\
No of observation & 200 & 200 \\
Log likelihood function & -31.04 & -29.5 \\
LR Chi & 47.3 & 29.7 \\
Pseudo $\mathrm{R}^{2}$ & 0.417 & 0.390 \\
\hline$* * * * * ; *$ significance at 1\%, 5\% and 10\% respectively; t-ratio in parenthesis
\end{tabular}


Figure 3 presents the Cumulative Distribution Function (CDF) for households with and without access to nonfarm income at different levels. The CDF of households without access to non-farm income stochastically dominated the CDF of households with access to additional

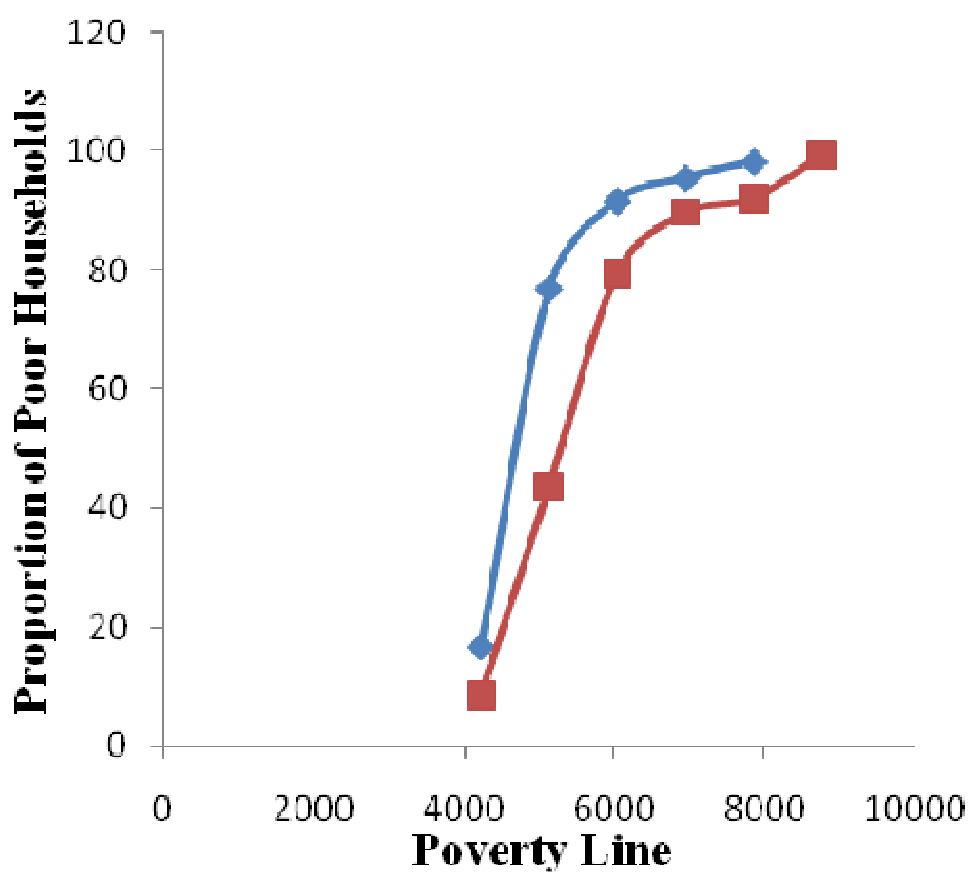

Figure 3: Dominance analysis by level of Income Earned by Household Heads

Thus, in Table 7, a rural household that earned at most $\$ 60,000$ without including non-farm income had poverty incidence of about $68 \%$ but the poverty incidence was reduced to $50 \%$ among the same group when extra earnings from non-agricultural activities were included.

Table 7: Identified poverty sub-groups based on incomewith and without extra earning

\begin{tabular}{|c|c|c|c|c|c|c|}
\hline \multirow[t]{2}{*}{ Variables } & \multirow{2}{*}{$\mathrm{P}_{0}$} & \multirow[t]{2}{*}{$\mathrm{P}_{1}$} & \multirow[t]{2}{*}{$\mathrm{P}_{2}$} & \multirow[t]{2}{*}{$\mathrm{n}$} & \multicolumn{2}{|c|}{ Share of poverty } \\
\hline & & & & & q & $\%$ \\
\hline \multicolumn{7}{|c|}{ Without extra earning ( } \\
\hline $20000-60000$ & 0.677 & 0.030 & 0.006 & 99 & 67 & 63.2 \\
\hline $60001-100000$ & 0.415 & 0.031 & 0.001 & 82 & 34 & 32.1 \\
\hline$>100000$ & 0.263 & 0.003 & 0.000 & 19 & 5 & 4.7 \\
\hline \multicolumn{7}{|c|}{ With extra earning( $)$} \\
\hline $20000-60000$ & 0.500 & 0.018 & 0.001 & 64 & 32 & 41.6 \\
\hline $60001-100000$ & 0.380 & 0.030 & 0.001 & 108 & 41 & 53.2 \\
\hline$>100000$ & 0.143 & 0.001 & 0.000 & 28 & 4 & 5.2 \\
\hline
\end{tabular}


According to Eboh, (2000), it is widely agreed that a capacity to diversify is beneficial for households at or below the poverty line. In addition to providing a strategic employment option outside Agriculture, the non-farm sector stimulates inter-sectoral linkages; reduce rural-urban migration, promote equitable distribution of income; broadens economic participation and enables the poor to smoothen inter-year and inter-season fluctuation of Agricultural labour demand and income.

\section{Hypothesis testing for income with or without ancillary occupation}

Table 8 shows the result of the hypothesis test comparing the mean of farmers with and without additional earning. The result proved a significant difference between farmers' income with and without additional earning of rural farming households. Since the average farm income with extra earning was greater than income from farming only, with a significant $t-$ value at $1 \%$, the null hypothesis which states that there is no significant difference between farm income with and without additional earning is therefore rejected.

Table 8: Test of hypothesis on difference between farmers' income with and without additional earning

\begin{tabular}{lllllll}
\hline Variables & Mean & N & SD & SE & t-value & t-critical \\
With & 67500.90 & 200 & 14152.9 & 5432.1 & 25.80 & 2.01 \\
Without & 46752.50 & 200 & 9765.3 & 3890.6 & & \\
\hline
\end{tabular}

$* * * P<0.01, S D=$ Standard Deviation, $S E=$ Standard Error

\section{Conclusions and Policy implications}

The study revealed that rural farming households were exposed to myriads of secondary occupations and extra earning from service or non-agricultural sector in rural areas and mostly urban centres. However, there is low probability that the urban economy will take care of rural household heads and their family members during off-farm season and/or provide enough employment for the growing rural labour force to allow a large proportion to move to the urban economy. The rural labour force must therefore have to find a way to improve their incomes in rural areas particularly during the dry season such as through continuous farming by irrigation activities, aquaculture, keeping livestock such as poultry and ruminant. However, in interim, it is recommended that the nonfarm employment should be developed among farm households to cater for rural households that are left fallowed during off-farm season.
It is suffice to note that incomes from both farming and the non-farming sectors will improve the standard of living through increase income. This could sharply enhance reduction in absolute poverty or apparently poverty alleviation in rural areas. Food insecurity may, however, continue to persist, except government encourages dry season farming through provision of infrastructures and irrigation facilities. Therefore, concerted effort by all stakeholders must encourage continuous farming throughout the year to avoid parttime farming which may become the dominant farm model, and could become a significant retardation of agricultural growth based on migration to industrial and service sectors. Finally, in view of the fact that farmers engages in secondary occupations partly due to volatile nature of agricultural production system, suggests also that any policy aimed at improving the livelihood strategies and standard of living of the rural farming households in the study 
area should at least for now target both primary and secondary occupations.

\section{References}

Akangbe, J.A., Adesiji, G. and Akinpelu, O.I. (2006). Effect of youth migration on farmers' agricultural production in Egbedore LGA of Osun State, Nigeria. Proceeding of the $8^{\text {th }}$ National Research Conference and Network held in University of Ilorin, Nigeria.

Ali, M. (2013). "Status of Informal Work Force in Urban Masses: a Case Study of Northern Ethiopia". International Journal of Scientific Research, 2(3): 192-198.

Ali, M. (2014). Socio-economic analysis of daily labourers in urban masses: a case study of Northern Ethiopia. Ethiopian J. of Environmental Studies \& Management 7(1): 50-58.

Csaki, C. and Lerman, Z. (2000). Agricultural Transition Revisited: Issues of Land Reform and Farm Restructuring in East Europe and the Former USSR. Washington DC: WB.

Central Bank of Nigeria (2006). Annual Report and Statement of Accounts. CBN Publications Abuja, Nigeria. PP.576-578.

Cragg, J.G. (1971). Some Statistical Models for Limited Dependent Variables with Applications to the Demand for Durable Goods. Econometrica, 39: 829-844.

Damisa, M.A., Sanni, S.A., Abdoulaye, T., Kamara A.Y. and Ayanwale A. (2011).Household Typology Based Analysis of Livelihood Strategies and Poverty Status in the Sudan Savannah of Nigeria: Publics. J. of Agric. and Envi. Studies, 2(1): 146- 160.

Damisa, M.A. and Hassan, M.B. (2009). Analysis of Factors Influencing the Consumption of Poultry Meat in the Zaria Emirate of Kaduna State,
Nigeria. European J. of Educational Studies, 1: 1-5.

Davis, J. and Bezemer, D. (2004). The Development of the Rural Non-Farm Economy in Developing Countries and Transition Economies: Key Emerging and Conceptual Issues.Chatham, UK: Natural Resources Institute.

Davis, B., Winters, P., Reardon, T. and Stamoulis, K. (2009). Rural nonfarm employment and farming: household level linkages. Agricultural Economics, 20(2):119-123.

De Janvry, A., Sadoulet, E. and Zhu N. (2005). The role of Non-farm incomes in reducing poverty and inequality in China. CUDARE working paper 1001, Berkeley: University of California.

Eboh, E.C. (2000). "Economic Diversification, Rural Non-farm sector and Poverty Alleviation towards Sustainable Rural livelihoods in Nigeria. In: Nwosu, A.C. Nwajiuba, C.U and Mbanasor, J.A (Eds). Agricultural Transformation in Nigeria: Owerri Novelty Industrial Enterprises, Pp. 242-253.

Economic Associate, (2010). "Overview of Nigeria's Economic Outlook". ICRISAT-UBN conference paper on Financing Agricultural Value Chain in Sub Saharan Africa, $16^{\text {th }}-17^{\text {th }}$ June 2011.

El Osta, H., Ahearn, M. and Mishra, A. (2004). Labour supply by farm operators underde coupled farm program payments. $R$. of Economics of the Household, 2(4): 367-385.

Ellis, F. (1998). Household strategies and rural livelihood diversification. The Journal of Development Studies, 35(1): 1-38.

Food and Agriculture Organization, (2013). FAO Country Programming 
Framework (CPF) Federal Republic of Nigeria, Fiat Panis, pp 1-41.

Foster, J.J., Greer, J. and Thorbecke, E. (1984). A Class of Decomposable Poverty Measures. Econometrica, 52: 761-765.

Goodwin, B. and Mishra, A. (2004). Farming efficiency and the determinants of multiple jobholding by farm operators. American Journal of Agricultural Economics, 86(3): 722-729.

Jama'are, A.S. (2000). ${ }^{e}$ Mechanization for Sustainable Agricultural Production in the $21^{\text {st }}$ Century". Paper presented at the $33^{\text {rd }}$ Annual Conference of Agricultural Society of Nigeria, Badeggi, Niger State.

Idowu, A., Aihonsu, J., Olubanjo, O. and Shittu, A. (2011). Determinants of IncomeDiversification amongst Rural Farm Households in Southwest Nigeria. Economics and Finance Review, 1(5): 31 - 43.

Idowu, A.O., Ojiako, I.A. and Ambali, O.I. (2013). Participation and Wage of Rural FemaleHeaded Households in Nigeria Non-Farm Employment. European Scientific Journal, 9(13): 194-219.

Lanjouw, P. and Murgai, R. (2009). Poverty decline, agricultural wages, and non-farm employment in rural India: 1983-2004. Agricultural Economics, 40(2): 243-264.

Matshe, I. and Young, T. (2004). Off-farm Labour Allocation Decisions in Small-Scale Rural Households in Zimbabwe. Agricultural Economics, 30: 175-186.

Nasai, D.H. (2010). Factors Influencing Livelihood Diversification among Rural Farmers in Giwa LGA of Kaduna State. An M Sc Agricultural Extension and Rural Soc. Ahmadu Bello University, Zaria, Nigeria.
National Bureau of Statistics (NBS) (2010, 2012, 2013, 2014). Poverty Profile for Nigeria. Annual Report, various volumes. Federal Republic of Nigeria.

National Population Commission (NPC) (2006). Population Census of the Federal Republicof Nigeria. Analytical Report at the National Population Commission, Abuja, Nigeria.

Nicodemo, C. (2007). Participation and wage equations for married women in European countries. A preliminary paper prepared from University of Tor Vergata, Rome.

Oladimeji, Y.U. (1999). An Economic Analysis of Artisanal Fisheries in Kwara State, Nigeria. Unpublished MSc Thesis. Federal University of Technology, Akure, Nigeria.

Oladimeji, Y.U., Abdulsalam, Z, and Damisa, M.A. (2014). Determinants of Poverty among Rural Artisanal Fishery Households in Kwara State, Nigeria. Journal of Sustainable Development in Africa, 16(3): 13-26.

Oladimeji, Y.U. (2015). Analysis of Poverty Status of Rural Artisanal Fisherfolks in Kwara State, Nigeria. Unpublished PhD Dissertation, Ahmadu Bello University, Zaria.

Oladimeji, Y.U., Abdulsalam, Z., Ajao, A.M. and Adepoju, S.A. (2015). Determinant of Rural Household Poverty Nexus Fuel Consumption among Fisherfolks in Kwara State, Nigeria. Journal of Scientific Research and Reports, 7(3): 185-194.

Olaoye, O.J., Idowu, A.A., Omoyinmi, G.A.K., Akintayo, I.A., Odebiyi, O.C. andFashina, A.O. (2012). Socialeconomic analysis of artisanal fisher folks in Ogun water-side Local Government Areas of Ogun State, Nigeria. Global Journal of Science 
Frontier Research Agriculture and Biology, 12(4): 8-22.

Reardon, T.J., Berdeque, J. Esual, (2001). Rural Non-farm employment and income in Latin America. Overview and policy implication: World Development, 29(3): 592-547.

Serra T., Goodwin, B. and Featherstone, A. (2005). Agricultural policy reform and off-farm labour decisions. Journal of Agricultural Economics, 56(2):271-285.

Shiferaw, B.A., Kebede, T.A. and You, L. (2008). Technology Adoption under Seed Access Constraints and the Economic Impacts of Improved
Pigeon pea Varieties in Tanzania. Agricultural Economics, 39: 309-323.

UN (2005). "Department of Economic and Social Affairs Statistics Division, Demographic and Social Statistics Branch", United Nations.

UNICEF (2010). "Understanding Urban Inequalities in Bangladesh: A Prerequisite for Achieving Vision 2021-A study based on the results of the 2009 Multiple Indicator Cluster Survey."www.unicef.org/bangladesh/ Urban_paperlowres.pdf.

Weersink, A. (1992). Off-farm labour decisions by Ontario Swine Producers. Canadian Journal of Agricultural Economics, 40: 235-251. 